\title{
SZEMLE
}

Educatio 27 (4), pp. 734-737 (2018)

DOI: $10.1556 / 2063.27 .2018 .4 .15$

\section{A BizAlomvesztés ÁrA}

\author{
SAMU FLÓRA
}

\begin{abstract}
Budapesti Corvinus Egyetem; MTA TK „Lendület” Research Center for Educational and Network Studies (RECENS)
\end{abstract}

Pamela Shockley-Zalabak, Sherwyn Morreale \& Michael Hackman: Building the High-Trust Organization: Strategies for Supporting Five Key Dimensions of Trust. San Francisco, 2010. Jossey-Bass. $x v+256$ p. ISBN 978-0-470-39472-4

„Az emberek azért mennek el [egy szervezettöl], mert távozásra késztetik őket, nem pedig egy jobb állás miatt."

A bizalom a leggyakrabban vizsgált fogalom a szervezeti kutatásban, ugyanis alapvető szerepe van a szervezeten belüli együttmüködés fenntartásában, különösen napjaink gyorsan változó, kihívásokkal teli gazdasági környezetében. A Building the High-Trust Organization c. könyv szervezetek vezetői számára ad iránymutatást egy hatékony, a bizalom magas szintjére épülő szervezet létrehozására. A könyv alapfeltevése, hogy a bizalom növekedése pozitív hatással van a munkavállalók és a szervezetek teljesítményére, míg a bizalomvesztés jelentős költségeket jelent a szervezet számára. Sőt, a könyv szerzői nem kevesebbet állítanak, mint hogy a bizalom az egyik legfontosabb alapeleme a szervezeti müködésnek.

A könyv hátterében álló kutatást a Nemzetközi Üzleti Kommunikációs Szervezet, az IABC (International Association of Business Communicators) finanszírozta, ennek megfelelően a kötet, jóllehet olvasmányos formában és főleg vezetők számára íródott, eleget tesz a szakmai megalapozottsággal kapcsolatos követelményeknek is. A közel 60 szervezetnél gyüjtött empirikus tapasztalatokat, példákat a szerzők gyakran használják egy-egy téma illusztrálására. Bár a közérthetőség érdekében az állítások alátámasztására használt hivatkozások ritkábbak a szakmai tanulmányoknál megszokottnál - így kissé nehezebb utánanézni olyan részeknek, amelyek behatóbban érdekelnék az olvasót -, a könyv szerzőinek a területen szerzett tekintélyes tapasztalata bizalmat kelt az olvasóban.

A szervezeti kutatásokon belül kevés olyan munka született, amely különböző bizalomfogalmakkal dolgozik, és ezek konvergálálára is képes (Jong-KroonSchilke 2017). A könyv öt, egymással szorosan összefüggő témát tárgyal, amely univerzálisan - kultúrától, nyelvtől, vállalkozástípustól és mérettől függetlenül

1 „[W]orkers leave because of pushes, not because they were pulled away by better job offers." (Itt a könyv Leigh Branham szavait idézi, 112. o.) 
- szerepet játszik a szervezeti bizalom építésében: alkalmasság (competence), nyíltság és öszinteség (openness and honesty), odafigyelés az alkalmazottakra és más érintettekre (concern for employees/ stakeholders), megbízhatóság (reliability) és azonosulás (identification). A szerzők erre az öt dimenzióra és ezek bizalommal való összefüggésére alapozva kidolgoztak egy mérőeszközt, amellyel értékelhetővé és érthetővé válnak a szervezeti gyakorlatok és folyamatok, valamint ezek bizalomra gyakorolt hatásai.

$\mathrm{A} z$ öt dimenzió összefüggése elméletben nyilvánvalónak tűnik, a kötet szerzői azonban felhívják a figyelmet a gyakorlati alkalmazás nehézségeire. Eredményes szervezeti múködéshez mind az öt dimenzióban elengedhetetlen a bizalmi szint folytonos fenntartása, ehhez pedig folytonos értékelésre van szükség. Az egyes dimenziók bemutatását követően a fejezetek végén a szerzők kérdések formájában támogatást is nyújtanak az értékeléshez.

A szerzők külön alfejezetekben hívják fel a figyelmet a bizalomvesztés negatív hatásaira, ugyanis azt tapasztalták, hogy a szervezetek ezeket gyakran alábecsülik. A könyv mintájára a következőkben én is példákkal illusztrálom a bizalomvesztés különböző eseteit a könyvben tárgyalt öt fö szempont mentén.

A vezetői alkalmasságot és az abba vetett bizalmat többnyire a környezeti kihívásoknak és a szervezeti céloknak való megfelelés alapján értékelik a szervezet dolgozói, és ennek alapján hoznak döntést a szervezettel való együttmüködésről. Az tehát, hogy mennyire bíznak a felek abban, hogy a vezetőség alkalmas a célok elérésére, illetve hogy hatékonyan képes-e válaszolni a szervezetet érintő kihívásokra, hatással van a szervezet teljesítményére.

$\mathrm{A} z$ alkalmasságba vetett bizalom szervezetenként eltérő lehet, hiszen függ az adott szervezet céljától és elképzeléseitől.
Minél tisztábbak, ambíciózusabbak ugyanakkor realisztikusak - egy szervezet céljai, annál könnyebb azoknak megfelelöen menedzselni egy szervezetet, és annál könnyebb a vállalati stratégiát a célokhoz igazítani. Bizalmatlanságot szül azonban a dolgozók körében, ha egy vezető tevékenysége nincs összhangban a szervezet céljaival. Széles körű felháborodást és bizalomvesztést keltett például az az eset, ahol egy, a függetlenség elvét valló szervezet menedzsere, egy válsághelyzet megoldása érdekében, a vezérigazgatót az autonómia részleges feladásáról próbálta meggyőzni. A menedzser levele, a vezetői alkalmatlanságáról alkotott véleményekkel párhuzamosan, hamar elterjedt a dolgozók között. $\mathrm{A} z$ eset csak tovább erősítette a válsághelyzetből fakadó bizonytalanságot, rontva a szervezet válságkezelési esélyeit.

Egy nyilt és őszinte szervezet képes arra, hogy biztosítsa a szükséges információk áramlását, mely által lehetőséget teremt építő jellegü gondolatcserére a szervezet minden szintjén. A nyílt és őszinte szervezetben dolgozók bíznak abban, hogy hozzáférhetnek az őket érintő információkhoz, bíznak ezen információk igazságtartalmában, és bíznak abban is, hogy a vezetőség ösztönzi és támogatja a tudásáramlást, ötletek cseréjét, kérdések megvitatását. A szerzők szerint az egyének közötti akadálymentes kommunikáció - a szervezet minden szintjén - kulcsfontosságú a problémamegoldás, a válságkezelés és az innováció szempontjából.

Magas bizalmi szinten vannak azok a szervezetek, amelyek meghallgatják és mérlegelik dolgozóik véleményét a szervezettel kapcsolatos döntések előtt. Rontja viszont a teljesítményt, ha a dolgozók azt érzékelik, hogy nincs hozzáférésük az őket közvetlenül is érintő információkhoz. Szemléltető példa a bizalomvesztésre az az eset, ahol a szervezet vezetője egy szervezeti részleg képviseletét ellátó, több- 
nyire kritikus álláspontot képviselő munkatársat úgy zárt ki a stratégiai ügyeket tárgyaló üléséről, hogy hatalmi pozícióját felhasználva a részleg képviseletére más, a részlegre újonnan érkező, kevésbé integrálódott személyt nevezett ki. A véleménynyilvánítás lehetőségének korlátozását és az információ ilyen jellegü visszatartását a dolgozók a hatalommal való visszaélésként élték meg, ami értelemszerüen növelte a bizalmatlanságot a szervezetben, és a dolgozók alacsonyabb motiváltságát, sokuk távozását eredményezte.

A bizalomépítés elengedhetetlen alkotóeleme az alkalmazottakra és a fogyasztókra való odafigyelés, amely leginkább az olyan mindennapi gyakorlatok során válik érzékelhetővé, mint például a munkaerőfelvétel, teljesítményértékelés, előléptetési és konfliktuskezelési politikák.

Magas bizalmi szinten értékelik a dolgozók azokat a szervezeteket, ahol a munkatársakat teljesítményük alapján igazságosan és arányosan jutalmazzák, de azokat a szervezeteket is, ahol a felső- és középvezetők rendszeresen érdeklődnek a dolgozóik jóllétével kapcsolatban. Fordítva, bizalmatlanságot ébreszt, ha egy szervezet vezetője még formális úton sem tart kapcsolatot a dolgozóival.

Nemcsak törődés formájában jelenhet meg ez a fajta odafigyelés. Szorosan összefügg a nyílt és őszinte információáramlással az is, amikor az alkalmazottak azt mérlegelik, hogy van-e lehetőségük kifejezni esetleges aggodalmaikat a vezetőség felé. A korábban felhozott példánál maradva, a képviselöjüket kitiltott részlegen dolgozók kifejezték aggodalmukat a részleg vezetőjének leváltásával kapcsolatosan, érdemi választ azonban nem kaptak. A dolgozók úgy érezték, a vezető nem törődik a problémájukkal. A bizalomvesztés ebben az esetben az alulról érkező további problémák jelzése elé állított akadályt, nehezítve ezzel a korrekt helyzetértékelést.

A szervezet vagy a vezetők megbizhatósága a kötelezettségvállalások betartásában nyilvánul meg. A dolgozók olyan vezetővel tudnak közösséget vállalni, akinek a cselekedetei illeszkednek a szavaihoz, akire stabilan számíthatnak a munkájuk során. A példaként felhozott szervezet vezetője mielőtt kitiltotta volna a részlegvezetőt a stratégiai ülésről, a csapatot arról biztosította, hogy a részlegvezető döntési hatásköre semmilyen szempontból sem fog csökkenni a közeljövőben. A fenti példa jól illusztrál egy, a vezető ígéretei és cselekedetei közötti inkonzisztenciát (másképp cselekedett, mint beszélt) és az ebből következő bizalomvesztést.

A vezetőség megbízhatósága láthatóan párhuzamba állítható az elsőként tárgyalt vezetői alkalmasság dimenzióval, azzal a kívánalommal, hogy a vezetők viselkedése legyen konzisztens a szervezeti célokkal. A vezetők megbízhatósága ugyanakkor szintén nem független a nyílt és őszinte kommunikációtól, ezek egymást erősítik a szervezeti bizalom előmozdításában.

A szervezettel való azonosulás akkor lehetséges, ha az egyént és a szervezetet hasonló értékek kötik össze. Az erős kapcsolódás egy ideig védelmet nyújt az egyének és a szervezet számára a bizonytalansággal és a belöle fakadó negatív következményekkel szemben, időt ad a problémák leküzdésére. A korábbi példában sajnos nyitott kérdés maradt az újonnan kinevezett vezető szervezeti értékekkel való azonosulásának kérdése és ennek hatása a szervezeti bizalomra. A szerzők ismét felhívják a figyelmet arra, hogy egy szervezet kizárólag akkor tudja motiválni erős kötődésü dolgozóit, ha a vezetők alkalmassága és megbízhatósága, a nyílt és őszinte kommunikáció, a dolgozókra való odafigyelés nem kifogásolható. 
A könyv jól bemutatja a témakör alapvető kérdéseit, amelyeket a szervezeti bizalommal foglalkozó jelenlegi kutatások is vizsgálnak. Hét évvel a könyv megjelenését követően készült egy metaelemzés, melyben Jong, Kroon és Schilke (2017) a szervezeti bizalommal foglalkozó 162 kutató és 347 tanulmány által felvázolt jövőbeni kutatási irányokat összegezték - az ott javasolt új irányok nagy részét az itt bemutatott könyv magában foglalja. A kötet ugyanis 1) többféle bizalomfogalmat vizsgál egyszerre (alkalmassággal vagy jóindulattal kapcsolatos bizalom), ezek 2) a szervezet több szintjén realizálódhatnak (bizalom egyénekben és szervezetekben). A szerzők 3) nemcsak oksági folyamatokra fókuszálnak, de 4) a bizalom mértékének többféle előzményét és számos következményét is sorra veszik. Tárgyalják 5) a bizalmi aszimmetria kérdéskörét, és 6) külön figyelmet szentelnek az észlelt és a tényleges megbízhatóság különválasztásának.
A kötet nemcsak bemutatja, hogy a bizalom megléte elengedhetetlen egy jól müködő csoport kialakulásához és fenntartásához, hanem a szerzők több országban szerzett tapasztalataik alapján a bizalom hatásainak általánosíthatóságát is megkísérlik. Amellett, hogy a kötet kiemeli a bizalom jelentőségét jól müködő csoportok kialakulásában, további különlegessége, hogy a világ több országában szerzett szervezeti tapasztalatok alapján képes a bizalom hatásainak általánosítására. Javaslom mélyebb olvasásra!

\section{IRODALOM}

Jong, B., Kroon, D. \& Schilke, O. (2017) The Future of Organizational Trust Research: A Content-Analytic Synthesis of Scholarly Recommendations and Review of Recent Developments. In: P. VAN LANge, B. Rockenbach \& T. YAmagishi (eds) Trust in Social Dilemmas. New York, Oxford University Press. pp. 173-194.

A cikk a Creative Commons Attribution 4.0 International License (https://creativecommons.org/licenses/ by/4.0/) feltételei szerint publikált Open Access közlemény, melynek szellemében a cikk bármilyen médiumban szabadon felhasználható, megosztható és újraközölhető, feltéve, hogy az eredeti szerző és a közlés helye, illetve a CC License linkje és az esetlegesen végrehajtott módosítások feltüntetésre kerülnek. (SID_1) 